J. Clin. Chem. Clin. Biochem.

Vol. 23, 1985, pp. 21-25

\title{
Observations of HDL Components in Female Probands Following an Ultra-Long Distance Run of 100 Miles
}

\author{
By $H$. Schriewer
}

Institut für Klinische Chemie und Laboratoriumsmedizin (Zentrallaboratorium)

Medizinische Einrichtungen der Westfälischen Wilhelms-Universität, Münster, FRG

K. Jung

Abteilung Sportmedizin des Fachbereiches 26 der Johannes-Gutenberg-Universität, Mainz, FRG

F. Emke and G. Assmann

Institut für Klinische Chemie und Laboratoriumsmedizin (Zentrallaboratorium)

Medizinische Einrichtungen der Westfälischen Wilhelms-Universität, Münster, FRG

(Received May 21/September 24, 1984)

Summary: The serum concentrations of total cholesterol and triglycerides as well as the cholesterol, phosphatidyl choline, and apolipoprotein components of HDL were tested in 19 participants immediately before and immediately after a 100-mile run.

After the run, taking into account any alterations in total protein, the following changes were observed: a decrease in total cholesterol $(p<0.001)$, as well as in triglycerides $(p<0.05)$, and an increase in HDL cholesterol $(p<0.05)$, and HDL phosphatidyl choline $(p<0.01)$. The concentrations of HDL apolipoprotein A-I and HDL apolipoprotein A-II were not affected.

The results indicate a change in composition of $\mathrm{HDL}$ following extreme prolonged physical exercise in women.

Zur Veränderung der HDL-Komponenten bei weiblichen Teilnehmern eines Ultralangstreckenlaufes über 100 Meilen

Zusammenfassung: Bei 19 weiblichen Teilnehmern eines 100-Meilen Laufes wurden unmittelbar vor und unmittelbar nach dem Lauf die Konzentrationen von Gesamtcholesterin und Triglyceriden sowie der Cholesterin-, Phosphatidylcholin- und Apolipoproteinkomponenten der HDL im Serum untersucht.

Bei Berücksichtigung von Veränderungen des Gesamteiweißes war nach dem Lauf eine Verminderung von Gesamtcholesterin $(p<0,001)$, und Triglyceriden $(p<0,05)$ sowie eine Erhöhung der Werte von HDLCholesterin $(p<0,05)$ und HDL-Phosphatidylcholin $(p<0,01)$ zu beobachten, während die Konzentrationen von HDL-Apolipoprotein A-I und HDL-Apolipoprotein A-II durch den Lauf nicht beeinflußt wurden.

Die Ergebnisse deuten auf eine Änderung in der Komposition der HDL nach extrem ausgedehnter körperlicher Ausdauerbelastung bei Frauen hin. 


\section{Introduction}

The analysis of high density lipoproteins (HDL) has in recent years shown that a low HDL cholesterol level can be considered a risk indicator for coronary heart disease $(1-5)$. Various research projects have shown that intensive physical activity leads to an increase in HDL cholesterol levels $(6-8)$. The majority of the research projects examining this effect, however, tend to treat physical exercise over a short period of time (9). There are relatively few reports on the influence of intensive and long-term exercise, such as a $100-\mathrm{km}$ run, and these furthermore usually relate to men $(10-13)$. The influence of long-term, intensive exercise on HDL levels in women is to date largely unknown.

HDL are not single substances but heterogenous groups of macromolecules $\left(\mathrm{HDL}_{1}, \mathrm{HDL}_{2}, \mathrm{HDL}_{3}\right)$ with different compositions, different metabolisms and different physicochemical properties. It is therefore impossible to deduce HDL mass or HDL composition from the HDL cholesterol value, or vice versa.

Obviously only the simultaneous determination of cholesterol and other HDL components (apolipoprotein A-I, apolipoprotein A-II, phospholipids) can reflect alterations in HDL mass and/or HDL composition. Nevertheless, until now, most post-exercise studies have determined HDL only in terms of their cholesterol content, not in terms of the other components.

The purpose of this study was to examine the influence of a 100 mile run on the concentrations of separate lipid and apolipoprotein components of HDL in female probands.

\section{Material and Methods}

The test group consisted of 19 female participants in a 100 mile run which took place on 26. 3. 1983 in Waldniel/FRG. The personal data and training conditions are summarised in table 1 . None of the participants were smokers, and none were taking medications with known influence on lipid metabolism. With the exception of 6 participants, the individuals tested consumed moderate amounts of alcohol (beer or wine). Blood samples were taken immediately before and immediately after the run. The conditions for taking the blood samples are listed in detail elsewhere (13). The sera where cooled to $+4^{\circ} \mathrm{C}$ and transported immediately to our laboratory.

\section{Analysis of HDL components}

Components of the total HDL fraction were analysed in the supernatant following precipitation of apolipoprotein Bcontaining lipoproteins with phosphotungstic acid/ $\mathrm{MgCl}_{2}$, using the Boehringer Mannheim test (test no. 400971) (14). For analysis of HDL cholesterol, the Monotest Cholesterol "high performance", Boehringer Mannheim, order no. 237574, was used. Analysis of HDL phosphatidyl choline was carried out by an enzymatic colour test, using the centrifugal analyser
Tabl.1. Personal data and training conditions of the female participants of the 100 mile run on 26. 3. 1983 in Waldniel/FRG

\begin{tabular}{llllc}
\hline $\begin{array}{l}\text { Age } \\
\text { (years) }\end{array}$ & $\begin{array}{l}\text { Height } \\
(\mathrm{cm})\end{array}$ & $\begin{array}{l}\text { Weight } \\
(\mathrm{kg})\end{array}$ & $\begin{array}{l}\text { Contra- } \\
\text { ceptives }\end{array}$ & $\begin{array}{l}\text { Training in } \\
\text { running per } \\
\text { week } \\
(\mathrm{km})\end{array}$ \\
\hline 55 & 158.0 & 49.3 & no & 120 \\
46 & 142.8 & 45.6 & no & 70 \\
63 & 162.7 & 53.9 & no & 65 \\
41 & 151.7 & 44.0 & no & 65 \\
49 & 166.4 & 67.0 & no & 70 \\
32 & 168.0 & 58.2 & no & 60 \\
40 & 161.0 & 52.1 & no & 130 \\
45 & 162.0 & 57.8 & no & 70 \\
47 & 157.9 & 50.8 & - & - \\
48 & 169.0 & 62.7 & yes & 70 \\
34 & 167.4 & 50.8 & no & 100 \\
42 & 157.5 & 51.6 & no & 80 \\
45 & 156.9 & 62.5 & - & 50 \\
54 & 172.8 & 63.4 & no & 120 \\
52 & 162.9 & 58.0 & no & 110 \\
40 & 172.0 & 64.0 & yes & 80 \\
41 & 162.7 & 57.3 & no & 50 \\
65 & 156.0 & 69.5 & no & 35 \\
48 & 155.4 & 59.5 & yes & 60 \\
\hline
\end{tabular}

Cobas Bio (Hoffmann La Roche). This method is described in detail elsewhere (15). HDL apolipoprotein A-I was determined using kinetic nephelometry, as described in detail elsewhere (16). Analysis of HDL apolipoprotein A-II was performed by radial immune diffusion, using antibody to human apolipoprotein A-II from rabbits (Immuno Co., Heidelberg, order no. 4833005). For calibration, Reference Standard Apolipoprotein Human, Immuno Co., Heidelberg, order no. 4910005 was used.

\section{Analysis of cholesterol and triglycerides}

Total cholesterol and triglycerides were analysed using the SMAC Autoanalyser (Technicon, Bad Vilbel, FRG) as previously described (17).

\section{Determination of total protein}

Total protein was analysed using the biuret method (18).

\section{Statistics}

To test for statistical significance, the Wilcoxon test for paired data was used. Results were expressed as mean \pm standard deviation.

\section{Results}

\section{Body weight, haematocrit, total protein}

After the run we found a slight reduction in body weight of $2.6 \pm 1.2 \%(p<0.001)$. Obviously, due to change in plasma volume, there was a statistically significant decrease in the haematocrit value from $41.9 \pm 2.7 \%$ to $37.6 \pm 2.6 \%$ ( $p<0.001)$. We found no statistically significant alterations in the total protein after the run $(67 \pm 0.4 \mathrm{~g} / \mathrm{l})$ compared to before 

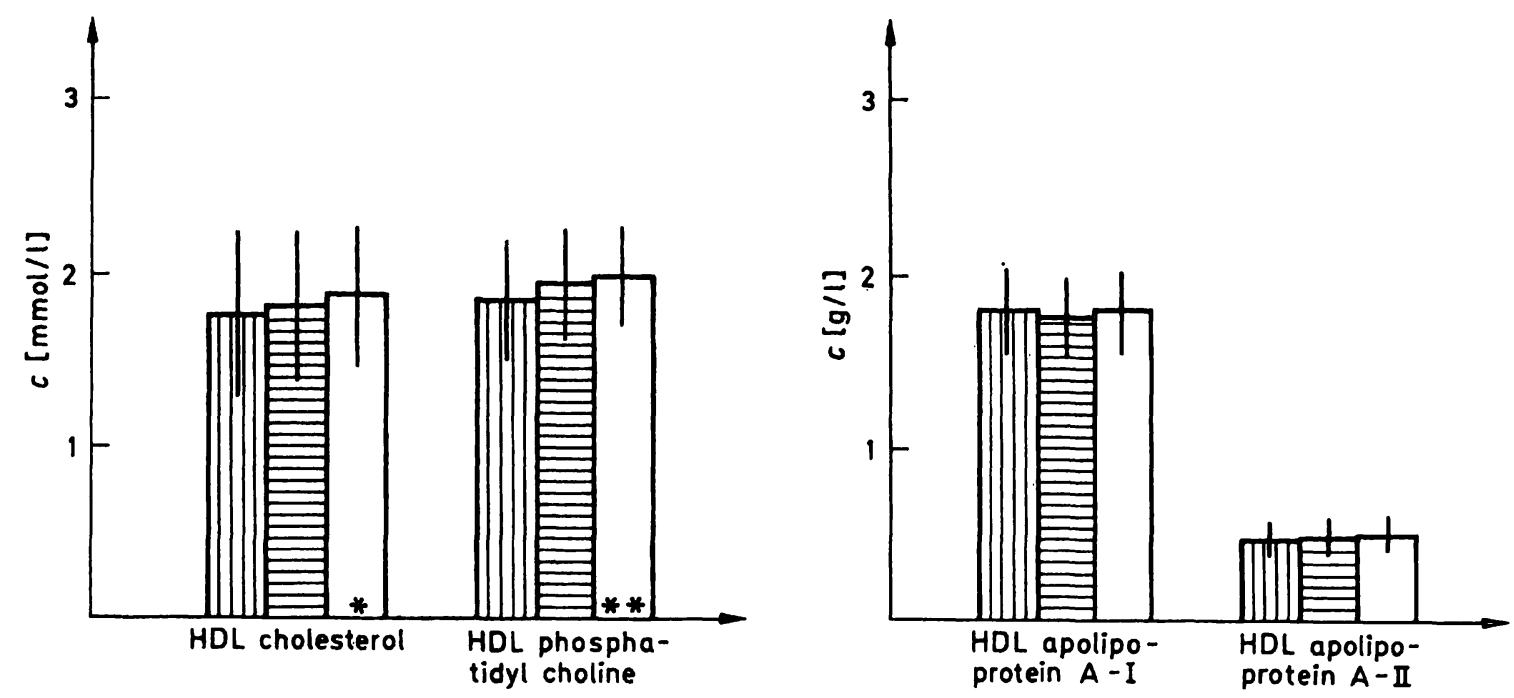

Fig. 1. Concentration of HDL components in female participants of the 100 mile run before the run and after the run (correction of the data obtained after the run with the quotient protein before the run/protein after the run, $n=19$ ).

( \pm \pm S.D.) $\square$ before the run, $\square$ after the run, $\square$ correction of the data after the run, $* p<0.05 * * p<0.01$

$(68 \pm 0.3 \mathrm{~g} / \mathrm{l})$. To compensate for any change in total protein, however, we multiplied the values found after the run with the quotient: total protein before the run/total protein after the run.

\section{Cholesterol and triglycerides}

Before the run we found a cholesterol value of 5.98 $\pm 1.24 \mathrm{mmol} / \mathrm{l}$ and a triglyceride value of $1.28 \pm 0.53$ $\mathrm{mmol} / \mathrm{l}$. The values found after the run, cholesterol: $5.37 \pm 1.12 \mathrm{mmol} / \mathrm{l}, \quad$ triglycerides: $1.11 \pm 0.35$ $\mathrm{mmol} / \mathrm{l}$, were obviously lower $(\mathrm{p}<0.001$ and $\mathrm{p}<0.05$ ) respectively).

\section{HDL Components}

The values of $\mathrm{HDL}$ cholesterol $(1.87 \pm 0.40 \mathrm{mmol} / \mathrm{l})$ and HDL phosphatidyl choline $(2.00 \pm 0.28 \mathrm{mmol} / \mathrm{l})$ after the run were approx. $6-7 \%$ higher than the corresponding previous values $(1.77 \pm 0.49 \mathrm{mmol} / \mathrm{l}$, $1.87 \pm 0.35 \mathrm{mmol} / \mathrm{l}$, respectively) $(\mathrm{p}<0.05$ and $\mathrm{p}<0.01$ respectively) (fig. 1$)$. After the run, HDL apolipoprotein A-I values $(1.81 \pm 0.21 \mathrm{~g} / \mathrm{l})$ and $\mathrm{HDL}$ apolipoprotein $A$-II values $(0.49 \pm 0.08 \mathrm{~g} / \mathrm{l})$ showed no statistically significănt difference from values found before the run $(1.80 \pm 0.24 \mathrm{~g} / 1$ and $0.48 \pm$ $0.09 \mathrm{~g} / 1$ respectively). As shown in figure 2 the ratios HDL cholesterol/HDL apolipoprotein A-I + A-II and HDL phosphatidyl choline/HDL apolipoprotein A-I + A-II were statistically significantly enhanced after the run.

\section{Discussion}

It has been observed that physical endurance training (jogging, swimming, cycling) for about $3-4 \times 30 \mathrm{mi}-$

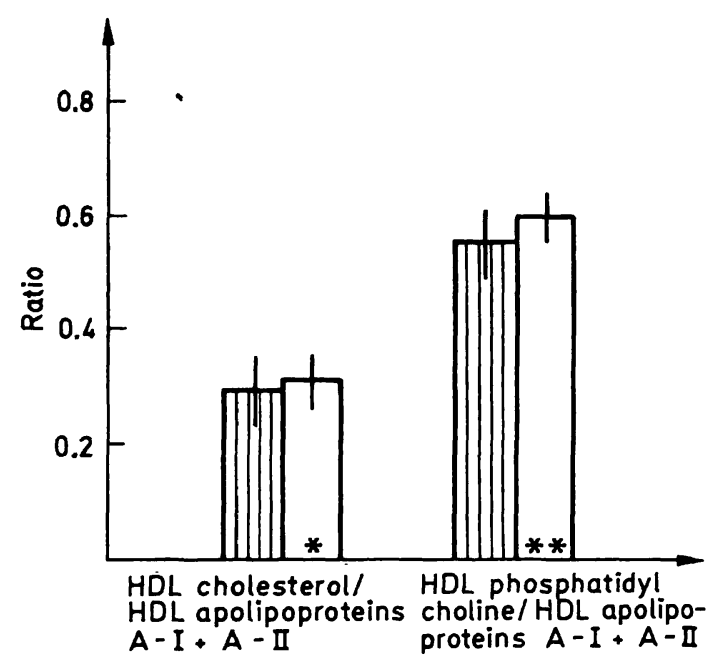

Fig. 2. HDL cholesterol/HDL apolipoproteins A-I + A-II and HDL phosphatidyl choline/HDL apolipoprotein A-I + A-II ratios in female participants of the 100 -mile run before and after the run, $(n=19)$. (x \pm S.D.) $\square$ before the run,

$\square$ after the run, $* \mathrm{p}<0.05 * \mathrm{p}<0.01$.

nutes per week leads to an increase in the HDL cholesterol level in blood serum (9). Although there are studies examining the influence on HDL cholesterol levels of short-term physical activity and physical training (9), there have so far been very few reports on the changes in HDL cholesterol following a single prolonged exercise session $(10-13)$. One study showed that male participants in a $100 \mathrm{~km}$ run had clearly higher HDL cholesterol values after the run (13). This increase in the HDL cholesterol level has also been observed in men after a 70-km ski long-run (11). In recently performed tests on participants of a 20-day marathon over $1100 \mathrm{~km}$, the participants also showed 
an increase in HDL cholesterol levels during the first five days (19). In another study on female participants in a $100 \mathrm{~km}$ run, increased $\mathrm{HDL}$ cholesterol levels were also found after the run (20). These previous results were confirmed by the results of the present study.

HDL comprise a heterogeneous mixture of macromolecules that differ with regard to particle size, chemical composition, and physical chemical properties. Therefore HDL cholesterol does not reflect HDL composition or HDL mass and vice versa. There are only a few reports on changes of the other HDL components following a severe endurance test. In a recent study of a 20 -day run over $1100 \mathrm{~km}$, no changes in apolipoprotein A-I values were observed during the first five days (19). Similarly, in male $100 \mathrm{~km}$ runners, differences in apolipoprotein A-I were not found when comparing pre- and post-exercise values (13). In females, however, after a $100 \mathrm{~km}$ run, higher HDL apolipoprotein A-I values were reported (20), while HDL apolipoprotein A-II concentrations did not differ before and after the run. It is of interest to note that the present study, in which females ran an obviously longer distance, no changes in HDL apolipoproteins were observed.

Along with the lack of information on HDL apolipoproteins, there are so far hardly any results available on changes of HDL phospholipids following a single, prolonged exercise session. Previously, we found that HDL phosphatidyl choline and HDL sphingomyelin values in males remained unchanged following a 100$\mathrm{km}$ run (13). In contrast to male $100-\mathrm{km}$ runners, however, female participants of a $100-\mathrm{km}$ run showed a clear decrease in HDL phosphatidyl choline after the run (20). The rise in HDL phosphatidyl choline

\section{References}

1. Miller, G. J. \& Miller N.E. (1975) Lancet $I, 16-19$.

2. Rhoads, G. G., Gulbrandsen, C. L. \& Kagan, A. (1976) New Engl. J. Med. 294, 293-298

3. Berg, K., Borresen, A. \& Dahlen, G. (1976) Lancet I, 499-502.

4. Castelli, W.P., Doyle, J.T., Gordon, T., Hames, C. G., Hjortland, M.C., Hully, S. B., Kagan, A. \& Zukel, M.J. (1977) Circulation 55, 767-772.

5. Gordon, T., Castelli, W.P., Hjortland, M.C., Kannel, W. B. \& Dawber, T. R. (1977) Ann. Int. Med. 87, 393-397.

6. Wood, P.D., Haskell, W., Klein, H., Lewis, H., Stern, M. P. \& Farquhar, J. W. (1976) Metabolism 25, 1249-1257.

7. Enger, S.Ch., Herbjornsen, K., Erikssen, J., Fretland, J. \& Fretland, A. (1977) Scand. J. Clin. Invest. 37, 252-255.

8. Huttunen, J.K., Länsimies, E., Voultilainen, E., Ehnholm, Ch., Hietanen, E., Penttilä, J., Sütonen, O. \& Rauramaa, R. (1979) Circulation 60, 1220-1229.

9. Dufaux, B., Assmann, G. \& Hollmann, W. (1982) Int. J. Sports Med. 3, 123-136. values in females after a 100-mile run, observed in the present study, considered in conjunction with changes in total protein, may be due to the increased length of the prolonged exercise.

It was the aim of the present study to optain information about the effects of prolonged exercise on HDL composition, by simultaneous determination of HDL cholesterol, HDL phosphatidyl choline, HDL apolipoprotein A-I and HDL apolipoprotein A-II. The increased concentrations of both HDL lipid components and the unchanged concentrations of both HDL apolipoproteins may be related to changes in the plasma levels of $\mathrm{HDL}_{2}$. Data published show that the lipid/protein ratio of $\mathrm{HDL}_{2}$ is higher than that of $\mathrm{HDL}_{3}$ (21). Alternatively, the enhanced ratios HDL cholesterol/HDL apolipoproteins A-I + A-II and HDL phosphatidyl choline/HDL apolipoprotein A-I + A-II after the run may reflect a change in the composition of the HDL particles in each density class. The changes in HDL composition observed after the run were paralleled by lower post-exercise triglycerides in comparison to pre-exercise values. It has been demonstrated that during lipolysis of triglyceride-rich lipoproteins, surface remnants are transported to $\mathrm{HDL}_{3}$ molecules, which thus become relatively rich in cholesterol and phospholipids (22). The enhanced lipolysis during the run may be based on induced lipoprotein lipase activity caused by the endurance training of the participants (see tab. 1). It has been demonstrated that well-trained long distance runners have higher lipoprotein lipase activities in muscle and fat tissue than non-athletes (23). Alternatively, besides lipoprotein lipase, reduced hepatic triglyceride lipase may be also involved (24).

10. Carlson, L. A. \& Mossfeld, F. (1964) Acta Physiol. Scand. 62, 51-59.

11. Enger, S. Ch., Stromme, S. B. \& Refsum, H.E. (1980) Scand. J. Clin. Lab. Invest. 40, $341-345$.

12. Jung, K. (ed.) (1981) Phänomen $100 \mathrm{~km}$ Lauf. Physiologische, medizinische und psychologische Aspekte, München. Schwarzeck-Verlag.

13. Schriewer, H., Günnewig, V. \& Jung, K. (1982) J. Clin. Chem. Clin. Biochem. 20, 533-536.

14. Assmann, G., Schriewer, H., Schmitz, G. \& Hägele, E. O. (1983) Clin. Chem. 29, 2026-2030.

15. Schriewer, H., Jung, G., Emke, F. \& Assmann, G. (1983) J. Clin. Chem. Clin. Biochem. 21, 611-614.

16. Assmann, G., Schriewer, H. \& Funke, H. (1981) J. Clin. Chem. Clin. Biochem. 19, 273-278.

17. Assmann, G., Oberwittler, W., Schulte, H., Schriewer, H., Funke, H., Epping, P. H., \& Hauss, W. H. (1980) Internist $21,446-459$. 
18. Weichselbaum, T.E. (1946) Amer. J. Clin. Pathol. 10, 40-49.

19. Schriewer, H., Jung, K., Günnewig, V. \& Assmann, G. (1983) Ann. Sports Med. 1, 71 - 74.

20. Schriewer, H., Jung, K., Emke, F. \& Assmann, G. (1984) Int. J. Sports Med. 5, 209-212.

21. Kostner, G. M., Patsch, J. R., Sailer, S., Braunsteiner, H. \& Holasek, A. (1974) Eur. J. Biochem. 15, 611-621.
22. Patsch, J. R., Gotto jr., A. M. (1979) Die Rolle von "High Density" Lipoproteinen (HDL) im Katabolismus triglyzeridreicher Lipoproteine. In: Neue Aspekte in Diagnostik und Therapie von Hyperlipoproteinämien. (Greten, H., Lang, P.D. \& Schettler, G., eds.) G. Witzstock, BadenBaden, Köln, New York, pp. 17-21.

23. Nikkilä, E. A., Taskinen, M. R., Rehunen, S. \& Härkönen, M. (1978) Metabolism 27, 1661-1671

24. Kuusi, T., Saarinen, P. \& Nikkilä, E. A. (1980) Atherosclerosis $36,589-593$.

Prof. Dr. G. Assmann

Institut für Klinische Chemie und

Laboratoriumsmedizin

(Zentrallaboratorium)

der Med. Einrichtungen der WWU

Albert-Schweitzer-Straße 33

D-4000 Münster 


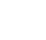

